\title{
Combined effects of endogenous sex hormone levels and mammographic density on postmenopausal breast cancer risk: results from the Breakthrough Generations Study
}

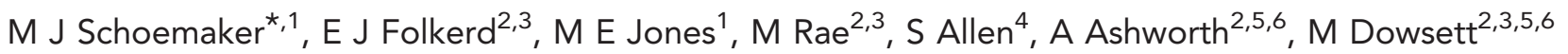 \\ and A J Swerdlow ${ }^{1,2}$ \\ ${ }^{1}$ Division of Genetics and Epidemiology, The Institute of Cancer Research, 15 Cotswold Road, London SM2 5NG, UK; ${ }^{2}$ Division of \\ Breast Cancer Research, The Institute of Cancer Research, 237 Fulham Road, London SW3 6JB, UK; ${ }^{3}$ Academic Department of \\ Biochemistry, Royal Marsden Hospital NHS Foundation Trust, Fulham Road, London SW3 6JJ, UK; ${ }^{4}$ Department of Diagnostic \\ Radiology, Royal Marsden Hospital NHS Foundation Trust, Downs Road, London SM2 5PT, UK; ${ }^{5}$ Breakthrough Breast Cancer \\ Research Centre, The Institute of Cancer Research, 237 Fulham Road, London SW3 6JB, UK and ${ }^{6}$ Division of Molecular Pathology, \\ The Institute of Cancer Research, 237 Fulham Road, London SW3 6JB, UK
}

Background: Mammographic density and sex hormone levels are strong risk factors for breast cancer, but it is unclear whether they represent the same aetiological entity or are independent risk factors.

Methods: Within the Breakthrough Generations Study cohort, we conducted a case-control study of 265 postmenopausal breast cancer cases and 343 controls with prediagnostic mammograms and blood samples. Plasma was assayed for oestradiol, testosterone and sex hormone-binding globulin (SHBG) concentrations and mammographic density assessed by Cumulus.

Results: Oestradiol and testosterone were negatively and SHBG positively associated with percentage density and absolute dense area, but after adjusting for body mass index the associations remained significant only for SHBG. Breast cancer risk was independently and significantly positively associated with percentage density $(P=0.002)$, oestradiol $(P=0.002)$ and testosterone $(P=0.007)$ levels. Women in the highest tertile of both density and sex hormone level were at greatest risk, with an odds ratio of 7.81 (95\% confidence interval (Cl): 2.89-21.1) for oestradiol and 4.57 (95\% Cl: 1.75-11.9) for testosterone and high density compared with those who were in the lowest tertiles. The cumulative risk of breast cancer in the highest oestradiol and density tertiles, representing $8 \%$ of controls, was estimated as $12.8 \%$ at ages $50-69$ years and $19.4 \%$ at ages $20-79$ years, and in the lowest tertiles was $1.7 \%$ and $4.3 \%$, respectively. Associations of breast cancer risk with tertiles of mammographic dense area were less strong than for percentage density.

Conclusions: Endogenous sex hormone levels and mammographic density are independent risk factors for postmenopausal breast cancer, which in combination can identify women who might benefit from increased frequency of screening and chemoprophylaxis.

\footnotetext{
*Correspondence: Dr MJ Schoemaker; E-mail: minouk.schoemaker@icr.ac.uk
}

Received 24 September 2013; revised 16 January 2014; accepted 16 January 2014; published online 11 February 2014 (c) 2014 Cancer Research UK. All rights reserved 0007-0920/14 
Mammographic density is one of the strongest risk factors for breast cancer, with a four- to fivefold increased risk in women whose breasts have at least $75 \%$ radiodense tissue compared with those with no or very little radiodense tissue (Boyd et al, 2011). Radiodense areas of the breast constitute epithelial and connective tissues, with non-dense radiolucent areas representing fatty tissue. Percentage density is known to decline with increasing age and body mass index (BMI), and is also associated with other established breast cancer risk factors, such as parity and menopause (Boyd et al, 2011). Density is known to be increased in women using combined hormone therapy (HT) and decreased in tamoxifen users (Martin et al, 2009). There is therefore potential for stratifying risk and acting as a biomarker of effectiveness of preventive interventions (Li et al, 2013).

Endogenous oestradiol and testosterone levels are positively associated with postmenopausal breast cancer risk (Key et al, 2002), and it is unclear to what extent their effects on breast cancer risk are independent of the effect of mammographic density or to what extent density is a reflection of underlying hormone levels.

The association between sex hormone levels and mammographic density is strongly influenced by BMI because obese women have higher oestradiol levels through aromatase activity in adipose tissue, lower sex hormone-binding globulin (SHBG) levels and, on average, lower percentage mammographic density due to the presence of adipose tissue than leaner women (Folkerd et al, 2006; Boyd et al, 2011). Analyses of the relation between endogenous hormone levels and mammographic density after taking account of BMI have shown inconsistent results (Boyd et al, 2002b; Aiello et al, 2005; Greendale et al, 2005; Tamimi et al, 2005; Warren et al, 2006; Bremnes et al, 2007; Verheus et al, 2007; Johansson et al, 2008; McCormack et al, 2009; Sprague et al, 2011).

Investigation of the combined effects of prior sex hormone levels and mammographic density on breast cancer risk is important for understanding of breast cancer aetiology and identification of women at raised risk of breast cancer. Only one study has examined this question previously, a case-control study of 252 cases (Tamimi et al, 2007), which reported that postmenopausal endogenous sex hormone levels and mammographic density were independently related to breast cancer risk, with risks being sixfold increased in women who were in the highest tertiles for both density and testosterone and four-fold increased for density and oestradiol compared with those in the lowest tertiles for both. Thus, it highlighted a potentially high-risk group of women and therefore needs re-examination in an independent study and a different population. We conducted analyses of the combined effects of these factors based on breast cancer cases that occurred in the Breakthrough Generations Study (BGS) cohort.

\section{MATERIALS AND METHODS}

Participants. Study subjects were identified from the BGS, a United Kingdom-based cohort study with over 113000 participants designed to investigate breast cancer aetiology (Swerdlow et al, 2011). Participants were initially recruited from mailing lists of supporters of the charity Breakthrough Breast Cancer and volunteers from the general population who then nominated friends and family as potential participants. They completed a postal questionnaire and, if willing (91.7\%), donated a blood sample, which were predominantly taken by general practitioner practices and posted to the study's laboratory on the same day. The baseline questionnaire consisted of 44 pages including comprehensive information on many breast cancer risk factors. Participants are contacted approximately every 3 years to collect follow-up information on breast cancer diagnoses and updated risk factor information. The study was approved by the South Thames
Multicentre Research Ethics Committee and participants provided informed consent.

The BGS contains a nested case-control study for analyses, where data collection for the full cohort is not feasible. Cases are subjects newly diagnosed with a primary invasive or in situ breast cancer since study entry and ascertained by the time of the analysis. Diagnoses were generally initially self-reported on follow-up questionnaires and were then confirmed by cancer registry, general practitioner or pathology records. One control per case is randomly selected from subjects who have been breast cancer free for at least as long as the matched case, within strata of categories of year and age at study entry, ethnicity and the number of days $(0-1,2, \geqslant 3)$ between blood draw and receipt of the blood sample in the laboratory, the latter to account for the effect of processing delays on measured plasma sex hormone concentrations (Jones et al, 2007). The current analysis is restricted to Caucasian women who were postmenopausal at blood draw, not on postmenopausal HT or other hormonal treatments at the time of blood draw or in the period 3 months before, and for whom we were able to retrieve non-symptomatic mammograms before diagnosis for cases and before the date a control reached a matched case's diagnosis age. Being postmenopausal was defined as having had a natural menopause at least 2 years before blood draw at cohort entry or having had a bilateral oophorectomy, or, for those whose menopausal status was unknown, having reached age 55 (current smokers) or 56 (never/former smokers) years at cohort entry. The inclusion criteria for this analysis led to incomplete matched casecontrol pairs, as a consequence of which we analysed the data incorporating the matching based on strata of selection to maintain statistical power.

Mammograms were retrieved from breast cancer screening centres, which under the National Breast Cancer Screening Programme invite women for routine 3-yearly screening from ages 50 to 70 years. Prediagnostic mammograms were digitised with a VIDAR Diagnostic Pro Plus scanner (VIDAR Systems Corporation, Herndon, VA, USA), which covers an optical density range of 0-3.85. Cumulus software (Sunnybrook Health Sciences Centre, Toronto, ON, Canada) was used for determination of percentage mammographic density and absolute dense and nondense area (Byng et al, 1994). All images were assessed by one observer, blinded to case-control status, who was trained by an experienced breast radiologist (S Allen). Two images per subject were selected, the left and right mediolateral oblique (MLO) views, from the most recent prediagnostic screening visit or most recent equivalent date for controls. The images were individually randomly allocated to batches of 100 . The batches included repeats, based on which the intraclass correlation coefficient was 0.97 for percentage density. Analyses were based on density readings of the views averaged between the left and right breast. Where MLO views could not be read, we used the craniocaudal views $(4.3 \%)$ or images from an earlier visit $(2.1 \%)$.

Sex hormone assays. Blood samples were centrifuged, separated into plasma and buffy coat, and stored in $-80{ }^{\circ} \mathrm{C}$ freezers on the day of receipt before transfer to liquid nitrogen tanks for long-term storage. Plasma oestradiol was measured by radioimmunoassay after organic extraction using a minor modification to a technique previously described and evaluated (Lee et al, 2006). Testosterone was measured using a solid-phase radioimmunoassay (Coata-Count SMN 10381047; Siemens Healthcare Diagnostics, Camberley, UK). Sex hormone binding globulin was measured using the Spectria SHBG IRMA kit (No. 68562; Orion Diagnostica, Espoo, Finland). The detection limits were $3 \mathrm{pmoll}^{-1}$ for total oestradiol, $0.14 \mathrm{nmoll}^{-1}$ for total testosterone and $1.3 \mathrm{nmoll}^{-1}$ for SHBG; 18 of the samples were below the limit for testosterone; for these we set the values to half the detectable limit. The intra- and interassay coefficient of variation $(\mathrm{CV})$ for oestradiol at a mean of 
$13 \mathrm{pmoll}^{-1}$ was $5.7 \%$ and $16 \%$, respectively, for testosterone at a mean of $2.3 \mathrm{nmoll}^{-1}$ the $\mathrm{CV}$ was $2.9 \%$ and $5.9 \%$, respectively, and for SHBG at a mean of $72 \mathrm{nmoll}^{-1}$ the CV was $3.8 \%$ and $8.3 \%$, respectively. The technician was blinded to case-control status. Batches of samples for assay contained 29 samples on average and included cases with their matched control as far as possible. All measurements were conducted in duplicate in the same batch except for 14 assays where only a single measurement was available owing to insufficient material. Free oestradiol and testosterone were estimated using previously reported formulae (Rinaldi et al, 2002).

Statistical analysis. We first assessed associations of mammographic density with sex hormone and SHBG levels among controls using linear regression modelling. We then assessed the odds ratio (OR) of breast cancer in relation to tertiles or quartiles of density and sex hormone levels, determined from the distribution among controls, using an (unconditional) logistic regression model, adjusted for the matching variables, age at first birth and parity, family history of breast cancer, age at menarche, age at menopause, duration of past HT use, alcohol consumption at cohort entry and BMI. In addition, all analyses of sex hormone and SHBG levels were adjusted for laboratory batch. Body mass index was derived from self-reported current height and weight. Tests for trend were based on log base 2 transformation for sex hormone and SHBG levels and square-root transformation for mammographic density, which was needed for the residuals to be normally distributed. We tested for multiplicative interaction between tertiles of sex hormone levels and density with a loglikelihood test comparing a model including the main effects and the cross-product of the factors with a model including only the main effects. All $P$-values are based on two-sided tests.

We estimated the cumulative risk of breast cancer between ages 50-69 and 20-79 years ('lifetime') for subjects according to tertiles of both sex hormone levels and density. Cumulative risks were based on the distribution of controls among tertiles, the respective ORs of breast cancer and the population cumulative risks between ages 50-69 and 20-79 years accounting for competing risks of mortality (Gail et al, 1989). Background rates were derived from breast cancer incidence rates and overall mortality rates for England and Wales averaged over 2006-2010, applying a correction for the study participants being never or former HT users with exposure prevalence and ORs from published literature (Reeves et al, 2006; Parkin, 2009). Approximate 95\% confidence intervals (CIs) were obtained by simulation.

In secondary analyses, we repeated the primary analyses restricted to never HT users. Analyses of breast cancer risk in relation to sex hormone levels were also conducted without adjustment for BMI. Analyses in relation to density were additionally adjusted for mammographic view and furthermore calculated using categories similar to those used in previous studies (Boyd et al, 2011). As a background check, we repeated analyses using complete matched case-control sets only. We also conducted additional analyses of combined effects of sex hormone levels and density using dichotomised categories to maximise statistical power and tested for multiplicative as well as additive interaction in this analysis (Rothman, 1986; VanderWeele and Knol, 2013).

\section{RESULTS}

We successfully retrieved prediagnostic mammograms for $75 \%$ of cases and $78 \%$ of controls who reported attendance at mammographic screening. Women for whom we retrieved mammograms were older and therefore more likely to be postmenopausal than women for whom we could not retrieve a mammogram, reflecting a higher retrieval rate in women with multiple historical triennial screening visits. The age difference was greater for cases (mean 58.2 vs 53.5 years) than for controls (mean 58.4 vs 56.0 years) (Supplementary Table S1). Among subjects with retrieved mammograms, 265 cases (52.8\%) and 343 controls (61.7\%) met the eligibility criteria to be assayed for sex hormone levels and were therefore included in the analysis. Among included subjects, the interval from the prediagnostic screening mammogram to the matching index date was greater for cases than for controls, and cases were on average younger at screening than controls owing to the most recent mammogram for cases frequently being diagnostic and therefore an earlier mammogram having to be considered (Table 1). The cases included 227 invasive and 38 in situ breast cancers. Cases and controls were similar with regard to the matching factors (Table 1). For three cases and nine controls images could not be read owing to poor resolution or implants.

Among controls, women with higher percentage mammographic density were younger and leaner (Table 2). Total oestradiol levels decreased by $10.0 \%(P<0.001)$ and free oestradiol by $12.4 \%$ $(P<0.001)$ per quartile increase in density when adjusted for laboratory batch and age at mammogram, which reduced to $3.2 \%$ $(P=0.261)$ and $4.6 \% \quad(P=0.114)$, respectively, after further adjustment for BMI. Decreases in density with testosterone levels were more modest: $4.3 \%(P=0.205)$ and $9.3 \%(P=0.009)$ for total and free concentrations, respectively, reduced to nonsignificant decreases of $1.7 \%$ and $4.6 \%$, respectively, after additional adjustment for BMI. Sex hormone-binding globulin levels were positively associated with density $(9.9 \%, P<0.001)$, with the association remaining significant after adjustment for BMI $(5.9 \%, P=0.006)$, or BMI plus total $(5.9 \%, P=0.007)$ or free $(5.1 \%, P=0.015)$ oestradiol, or BMI plus total $(6.0 \%, P=0.005)$ or free (5.2, $P=0.013$ ) testosterone (not in table). Absolute non-dense area was most strongly positively associated with sex hormone levels, in particular free-circulating oestradiol $(25.3 \%, P<0.001)$ and freecirculating testosterone $(14.7 \%, P<0.001)$ and was negatively associated with SHBG $(10.7 \%, P<0.001)$ (Supplementary Table $\mathrm{S} 2 \mathrm{~b})$. Associations of absolute dense area in relation with the analytes were weaker than those of percentage density, but statistically significant for most (Supplementary Table S2a).

Breast cancer risk was positively associated with mammographic percentage density (Table 3 ), with the OR in the highest quartile (median density $40.2 \%$ ) compared with the lowest quartile (median density 3.2\%) being 2.75 (95\% CI: 1.57-4.79). These associations became somewhat stronger after adjustment for sex hormones or SHBG. Odds ratios in relation to frequently reported categories of density were 1.81 (95\% CI: 1.13-2.90) for 10-24\%, 2.32 (95\% CI: $1.40-3.86$ ) for $25-49 \%$ and 2.37 (95\% CI: $1.04-5.41$ ) for $\geqslant 50 \%$ compared with $<10 \%$ density. Associations with absolute dense area were somewhat weaker than for percentage dense area (Supplementary Table S3).

Total and free oestradiol and testosterone levels were positively associated with breast cancer risk (Table 4). Odds ratios in the highest quartile compared with the lowest were greatest for free oestradiol $(\mathrm{OR}=2.42$; 95\% CI: $1.27-4.61)$ and of similar magnitude for total oestradiol $(\mathrm{OR}=2.07 ; 95 \% \mathrm{CI}: 1.11-3.84)$, total testosterone $(\mathrm{OR}=2.11 ; 95 \% \mathrm{CI}: 1.20-3.70)$ and free testosterone $(\mathrm{OR}=2.07$; 95\% CI: 1.15-3.74). Additional adjustment for percentage density (Table 4) or absolute dense area (not in table) did not materially affect these associations. Breast cancer risk was borderline significantly inversely associated with SHBG and significantly so after adjustment for percentage density $(\mathrm{OR}=0.58 ; 95 \% \mathrm{CI}$ : 0.31-1.10 for the highest quartile). Odds ratios of breast cancer in relation to sex hormone levels without adjustment for BMI were somewhat lower for oestradiol and stronger for testosterone than those reported after adjustment (not in table).

In analyses of the combined effects of percentage density and total sex hormone levels, the OR in women in the top tertile for both was 7.81 (95\% CI: 2.89-21.1) for oestradiol and 4.57 


\begin{tabular}{|c|c|c|c|c|}
\hline & \multicolumn{2}{|c|}{ Cases } & \multicolumn{2}{|c|}{ Controls } \\
\hline Characteristic & No. $^{a}$ & $\%$ & No. ${ }^{a}$ & $\%$ \\
\hline \multicolumn{5}{|c|}{ Age at entry (years) } \\
\hline$<60$ & 121 & 45.7 & 152 & 44.3 \\
\hline $60-69$ & 130 & 49.1 & 165 & 48.1 \\
\hline$\geqslant 70$ & 14 & 5.3 & 26 & 7.6 \\
\hline \multicolumn{5}{|c|}{ Year of entry to the study } \\
\hline$<2006$ & 132 & 49.8 & 155 & 45.2 \\
\hline 2006 & 71 & 26.8 & 103 & 30.0 \\
\hline 2007 & 40 & 15.1 & 55 & 16.0 \\
\hline$\geqslant 2008$ & 22 & 8.3 & 30 & 8.8 \\
\hline \multicolumn{5}{|c|}{ Days blood sample in post } \\
\hline $0-1$ & 216 & 82.1 & 278 & 81.3 \\
\hline 2 & 23 & 8.8 & 28 & 8.2 \\
\hline$\geqslant 3$ & 24 & 9.1 & 36 & 10.5 \\
\hline \multicolumn{5}{|c|}{ Age at mammogram (years) } \\
\hline$<60$ & 123 & 46.4 & 146 & 42.7 \\
\hline $60-69$ & 131 & 49.4 & 175 & 51.2 \\
\hline$\geqslant 70$ & 11 & 4.2 & 21 & 6.1 \\
\hline
\end{tabular}

Time of mammogram compared with diagnosis or index date

\begin{tabular}{|l|r|r|r|r|}
\hline$<1.0$ year earlier & 16 & 6.0 & 76 & 22.2 \\
$1-1.9$ years earlier & 39 & 14.7 & 101 & 29.5 \\
$2-2.9$ years earlier & 96 & 36.2 & 103 & 30.1 \\
$\geqslant 3.0$ years earlier & 114 & 43.0 & 62 & 18.1
\end{tabular}

Timing of mammogram compared with blood draw

\begin{tabular}{|l|r|r|r|r|}
\hline $2-3$ years earlier & 61 & 23.0 & 46 & 13.5 \\
$1-1.9$ years earlier & 57 & 21.5 & 60 & 17.5 \\
Within 12 months & 99 & 37.4 & 149 & 43.6 \\
$1-1.9$ years later & 22 & 8.3 & 32 & 9.4 \\
$\geqslant 2.0$ years later & 26 & 9.8 & 55 & 16.1 \\
\hline \multicolumn{4}{|l|}{} \\
Age at menarche (years) & 94 & 39.2 & 143 & 46.4 \\
\hline$<13$ & 67 & 27.9 & 74 & 24.0 \\
13 & 79 & 32.9 & 91 & 29.6 \\
$\geqslant 14$ & &
\end{tabular}

Age at first birth and parity

\begin{tabular}{|l|r|r|r|r|}
\hline Nulliparous & 27 & 10.2 & 36 & 10.5 \\
$<25$ years/1-2 children & 55 & 20.8 & 85 & 24.8 \\
$<25$ years/ $\geqslant 3$ children & 30 & 11.3 & 69 & 20.1 \\
$25-29$ years/1-2 children & 67 & 25.3 & 84 & 24.5 \\
$25-29$ years/ $\geqslant 3$ children & 39 & 14.7 & 29 & 8.5 \\
$\geqslant 30$ years/1-4 children & 47 & 17.7 & 40 & 11.7 \\
\hline Age at menopause (years) & 51 & 28.7 & 81 & 35.7 \\
\hline$<50$ & 99 & 55.6 & 123 & 54.2 \\
$50-54$ & 28 & 15.7 & 23 & 10.1 \\
$\geqslant 55$ & 144 & 56.7 & 160 & 50.2 \\
\hline Former use of postmenopausal hormone therapy (years) \\
\hline Never & 32 & 12.6 & 51 & 16.0 \\
$<5$ & 45 & 17.7 & 56 & 17.6 \\
$5-9$ & 33 & 13.0 & 52 & 16.3 \\
\hline 10 &
\end{tabular}

\begin{tabular}{|c|c|c|c|c|}
\hline \multirow[b]{2}{*}{ Characteristic } & \multicolumn{2}{|c|}{ Cases } & \multicolumn{2}{|c|}{ Controls } \\
\hline & No. ${ }^{a}$ & $\%$ & No. ${ }^{a}$ & $\%$ \\
\hline \multicolumn{5}{|l|}{ Body mass index $\left(\mathrm{kg} \mathrm{m}^{-2}\right)$} \\
\hline$<25.0$ & 120 & 45.8 & 162 & 47.8 \\
\hline $25.0-29.9$ & 97 & 37.0 & 128 & 37.8 \\
\hline$\geqslant 30.0$ & 45 & 17.2 & 49 & 14.5 \\
\hline \multicolumn{5}{|l|}{ Alcohol consumption (g per day) } \\
\hline None & 52 & 20.0 & 68 & 20.1 \\
\hline$<5$ & 36 & 13.9 & 48 & 14.2 \\
\hline $5-14$ & 88 & 33.9 & 91 & 26.9 \\
\hline$\geqslant 15$ & 84 & 32.3 & 131 & 38.8 \\
\hline Family history of breast cancer (yes) & 66 & 24.9 & 57 & 16.6 \\
\hline History of benign breast disease (yes) & 93 & 35.4 & 86 & 25.2 \\
\hline Total & 265 & 100.0 & 343 & 100.0 \\
\hline
\end{tabular}

(95\% CI: 1.75-11.9) for testosterone compared with those who were in the lowest tertile for both (Table 5). For SHBG, the OR was greatest in the lowest tertile of SHBG and the highest tertile of density $(\mathrm{OR}=2.23$; 95\% CI: $0.92-5.42)$. There was no statistical evidence for interaction between these factors on breast cancer risk. Analyses of absolute dense area instead of percentage dense area showed weaker associations (Supplementary Table S4).

Estimates of cumulative risk of breast cancer based on the above ORs for combinations of tertiles and background population rates for England and Wales were 12.8\% (95\% CI: 4.9-30.7\%) from ages 50 to 69 years and $19.4 \%$ (95\% CI: 8.8-42.0\%) between ages 20 and 79 years for women in the top tertiles of both oestradiol and density, and $1.7 \%$ (95\% CI: $0.61 \%-4.9 \%$ ) and $4.3 \%$ (95\% CI: $2.7 \%-$ $8.6 \%)$ for those in the bottom tertiles of both, whereas those in the general population were $6.0 \%$ and $10.2 \%$, respectively (Table 6).

In analyses restricted to never HT users, ORs for breast cancer were somewhat lower in relation to percentage density and to total oestradiol than for all study subjects combined, were similar for free oestradiol, free testosterone and SHBG, but stronger for total testosterone. Analyses of combined effects in this group were not conducted owing to small numbers. Analyses of density on breast cancer risk adjusted for mammographic view did not affect the results. Restricting the analysis to matched sets only did not materially affect the conclusions but affected the precision of the estimates. Analyses repeated with dichotomised categories of density and sex hormone levels did not reveal statistically significant interactions (Supplementary Table S5).

\section{DISCUSSION}

In our study, circulating oestradiol and testosterone levels and mammographic density were each independent risk factors for breast cancer. Women in the highest tertile of both mammographic percentage density and total oestradiol or testosterone were at over seven- and fourfold increased risk, respectively, compared with those in the lowest for both. On the basis of United Kingdom national cancer incidence rates, we estimate that women in the top tertile for both oestradiol and percentage density might be at cumulative risk of $12.8 \%$ between ages 50 and 69 years and $19.4 \%$ between 20 and 79 years, although approximate CIs were wide reflecting limited number of subjects in the tertile groups. Such risk 
Table 2. Association between plasma oestradiol, testosterone and SHBG levels and percentage mammographic density among control subjects: Breakthrough Generations Study, United Kingdom

\section{Percentage mammographic density (\%), quartiles ${ }^{a}$}

\begin{tabular}{|l|c|c|c|c|c|c|}
\hline Characteristic & 1st & 2nd & 3rd & 4th & $\begin{array}{c}\text { \% Increase per } \\
\text { quartile }^{\mathbf{b}}\end{array}$ & $\begin{array}{c}\boldsymbol{P} \text {-value } \\
\text { trend }^{\mathbf{b}}\end{array}$ \\
\hline No. of controls & 84 & 83 & 84 & 83 & \\
\hline Median percentage density (\%) & 3.2 & 11.8 & 22.2 & 40.2 & \\
\hline Mean age at mammogram (years) & 62.0 & 60.8 & 60.7 & 60.6 & & \\
\hline Mean BMl at cohort entry (kg m ${ }^{-2}$ ) & 28.0 & 25.4 & 26.5 & 24.1 & & \\
\hline
\end{tabular}

Geometric mean, adjusted for laboratory batch and age at mammogram

Oestradiol (pmoll-1)

Free oestradiol $\left(\mathrm{pmoll}^{-1}\right)$

Testosterone (nmoll ${ }^{-1}$ )

Free testosterone $\left(\mathrm{nmoll} \mathrm{I}^{-1}\right)$

SHBG $\left(\mathrm{nmoll}{ }^{-1}\right)$

\begin{tabular}{c|c}
\hline 22.6 & 19.9 \\
0.55 & 0.47 \\
0.64 & 0.56 \\
0.010 & 0.008 \\
37.3 & 42.3
\end{tabular}

20.8

0.49

0.62

0.009

42.5

15.6
0.35
0.53
0.007
51.0

\begin{tabular}{c|c}
-10.0 & $<0.001$ \\
-12.4 & $<0.001$ \\
-4.3 & 0.205 \\
-9.3 & 0.009 \\
9.9 & $<0.001$
\end{tabular}

Geometric mean, additionally adjusted for BMI

Oestradiol (pmoll $\left.{ }^{-1}\right)$

Free oestradiol (pmoll ${ }^{-1}$ )

Testosterone (nmoll ${ }^{-1}$ )

Free testosterone $\left(\mathrm{nmoll} \mathrm{I}^{-1}\right)$

SHBG $\left(\mathrm{nmoll}{ }^{-1}\right)$

\begin{tabular}{c|c}
19.7 & 20.8 \\
0.47 & 0.49 \\
0.62 & 0.57 \\
0.009 & 0.008 \\
39.9 & 41.5
\end{tabular}

\begin{tabular}{c|c}
\hline 20.2 & 17.9 \\
0.48 & 0.41 \\
0.62 & 0.56 \\
0.009 & 0.007 \\
43.1 & 47.8
\end{tabular}

Abbreviations: $\mathrm{BMI}=$ body mass index; $\mathrm{SHBG}=$ sex hormone-binding globulin.

${ }^{a} \mathrm{Q} 1$ : <6.58; Q2: 6.58-16.75; Q3: 16.76-29.60; Q4: > 29.60 percentage density.

bercentage change in sex hormone or SHBG level per quartile increase in percentage mammographic density, $P$-value based on Wald test.

Table 3. Odds ratios for incident breast cancer in relation to percentage mammographic density, Breakthrough Generations Study, United Kingdom

Percentage mammographic density (\%), quartiles ${ }^{a}$

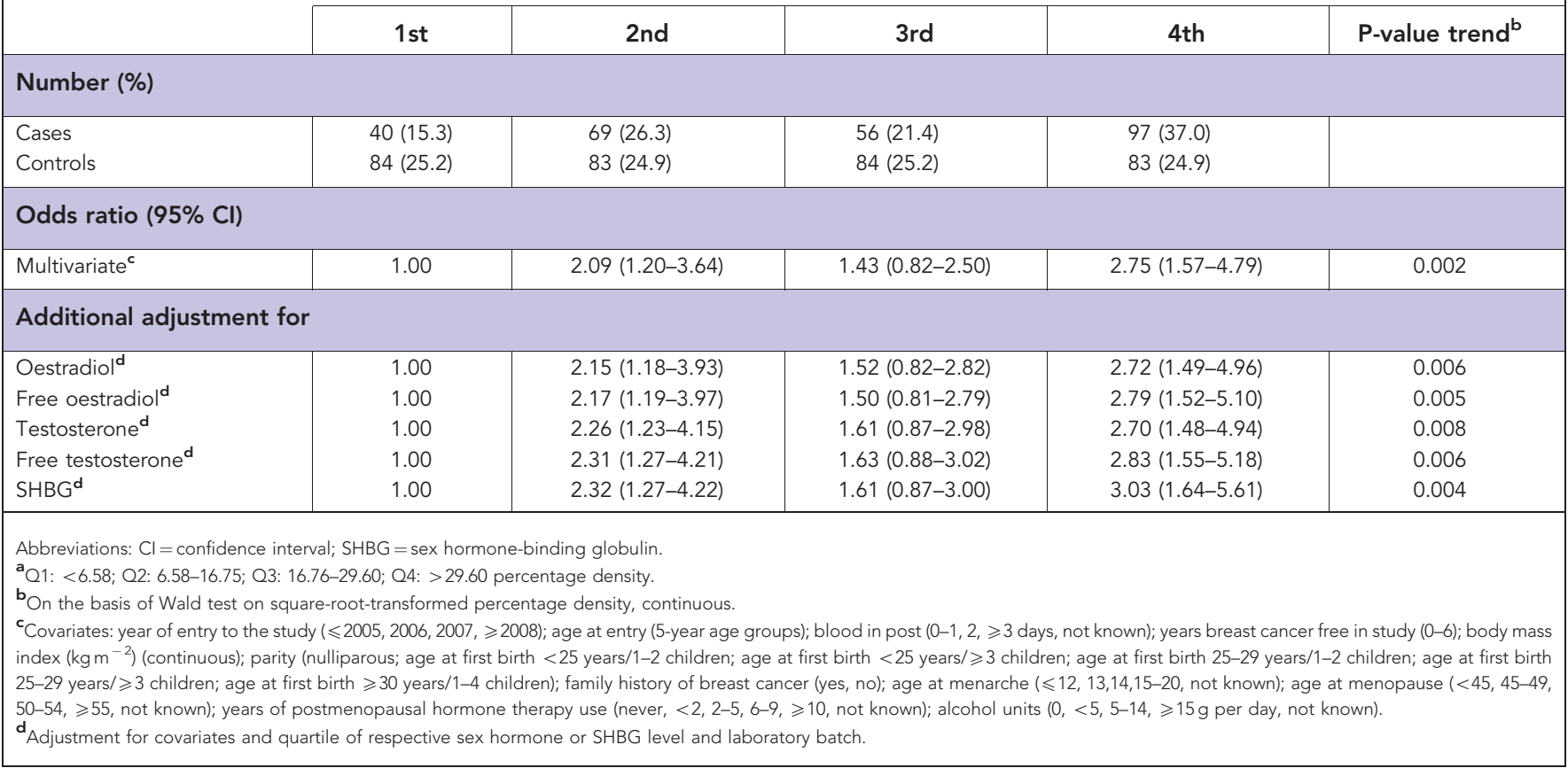

estimates in the top tertiles, representing $8.2 \%$ of controls in our study, are within the range of risk levels for which the National Institute for Health and Care Excellence recommends increased frequency of breast cancer screening and chemoprophylaxis
(National Institute for Health and Care Excellence, 2013). On the other hand, women in the lowest tertile for both have estimated cumulative risks of $1.7 \%$ at ages 50-69 years and $4.3 \%$ lifetime, considerably lower than that in the general population. 


\begin{tabular}{|c|c|c|c|c|c|}
\hline & \multicolumn{4}{|c|}{ Plasma hormone level, quartiles ${ }^{a}$} & \multirow[b]{3}{*}{$\begin{array}{l}P \text {-value } \\
\text { trend }^{b}\end{array}$} \\
\hline & $1 \mathrm{st}$ & 2nd & 3rd & 4th & \\
\hline Sex hormone or SHBG level/adjustment factors & & $\mathrm{OR}^{\mathrm{c}}(95 \% \mathrm{Cl})$ & $\mathrm{OR}^{\mathrm{c}}(95 \% \mathrm{Cl})$ & $\mathrm{OR}^{\mathrm{c}}(95 \% \mathrm{Cl})$ & \\
\hline \multicolumn{6}{|l|}{ Oestradiol } \\
\hline $\begin{array}{l}\text { Multivariate }^{c} \\
+ \text { Percentage density }^{d}\end{array}$ & $\begin{array}{l}1.00 \\
1.00\end{array}$ & $\begin{array}{l}1.18(0.67-2.09) \\
1.21(0.68-2.16)\end{array}$ & $\begin{array}{l}1.51(0.83-2.75) \\
1.49(0.81-2.75)\end{array}$ & $\begin{array}{l}2.07(1.11-3.84) \\
2.03(1.08-3.81)\end{array}$ & $\begin{array}{l}0.002 \\
0.004\end{array}$ \\
\hline \multicolumn{6}{|l|}{ Free oestradiol } \\
\hline $\begin{array}{l}\text { Multivariate }^{c} \\
+ \text { Percentage density }^{d}\end{array}$ & $\begin{array}{l}1.00 \\
1.00\end{array}$ & $\begin{array}{l}1.32(0.74-2.36) \\
1.46(0.81-2.63)\end{array}$ & $\begin{array}{l}1.72(0.95-3.13) \\
1.78(0.97-3.27)\end{array}$ & $\begin{array}{l}2.42(1.27-4.61) \\
2.48(1.29-4.78)\end{array}$ & $\begin{array}{l}0.001 \\
0.001\end{array}$ \\
\hline \multicolumn{6}{|l|}{ Testosterone } \\
\hline $\begin{array}{l}\text { Multivariate }^{c} \\
+ \text { Percentage density }^{d}\end{array}$ & $\begin{array}{l}1.00 \\
1.00\end{array}$ & $\begin{array}{l}1.34(0.75-2.37) \\
1.21(0.67-2.18)\end{array}$ & $\begin{array}{l}1.42(0.79-2.52) \\
1.36(0.76-2.44)\end{array}$ & $\begin{array}{l}2.11(1.20-3.70) \\
2.01(1.14-3.54)\end{array}$ & $\begin{array}{l}0.007 \\
0.009\end{array}$ \\
\hline \multicolumn{6}{|l|}{ Free testosterone } \\
\hline $\begin{array}{l}\text { Multivariate }^{c} \\
+ \text { Percentage density }^{d}\end{array}$ & $\begin{array}{l}1.00 \\
1.00\end{array}$ & $\begin{array}{l}1.47(0.82-2.64) \\
1.53(0.85-2.76)\end{array}$ & $\begin{array}{l}1.82(1.01-3.28) \\
1.87(1.03-3.40)\end{array}$ & $\begin{array}{l}2.07(1.15-3.74) \\
2.15(1.18-3.91)\end{array}$ & $\begin{array}{l}0.001 \\
0.001\end{array}$ \\
\hline \multicolumn{6}{|l|}{ SHBG } \\
\hline $\begin{array}{l}\text { Multivariate }^{c} \\
+ \text { Percentage density }^{d}\end{array}$ & $\begin{array}{l}1.00 \\
1.00\end{array}$ & $\begin{array}{l}1.10(0.63-1.90) \\
1.11(0.63-1.95)\end{array}$ & $\begin{array}{l}0.86(0.48-1.56) \\
0.74(0.40-1.37)\end{array}$ & $\begin{array}{l}0.64(0.35-1.20) \\
0.58(0.31-1.10)\end{array}$ & $\begin{array}{l}0.055 \\
0.024\end{array}$ \\
\hline 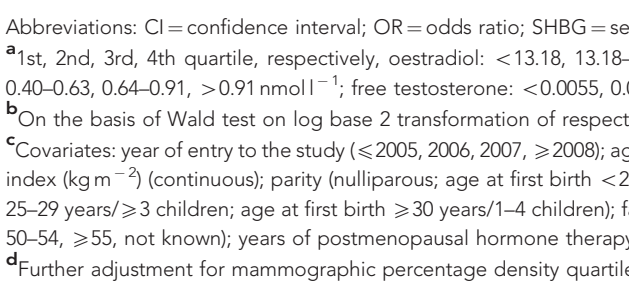 & $\begin{array}{l}\text { none-bi } \\
18.87-2 \\
.0087,0 \\
x \text { hormo } \\
\text { ntry }(5-y \\
\text { s/1-2 ch } \\
\text { history o } \\
\text { never, }\end{array}$ & $\begin{array}{l}\text { lobulin. } \\
29.38 \text { pmol }^{-1} \text {; free } \\
0138,>0.0138 \text { nmol } \\
\text { HBG value. } \\
\text { groups); blood in pos } \\
\text { age at first birth }<25 \\
\text { cancer (yes, no); age } \\
6-9, \geqslant 10, \text { not knowr }\end{array}$ & $\begin{array}{l}\text { liol: }<0.29,0.29-0.44, \\
\text { BG: }<31.30,31.30-43 \\
\geqslant 3 \text { days, not known), } \\
\geqslant 3 \text { children; age at firs } \\
\text { arche }(\leqslant 12,13,14,15 \\
\text { hol units }(0,<5,5-14,\end{array}$ & $\begin{array}{l}69,>0.69 \mathrm{pmoll}^{-1} ; \mathrm{t} \\
46-59.10,>59.10 \mathrm{nmo} \\
\text { preast cancer free in st } \\
25-29 \text { years/1-2 childr } \\
\text { t known); age at meno } \\
\text { per day, not known); }\end{array}$ & $\begin{array}{l}\text { terone: }<0.40 \text {, } \\
\text {-6); body mass } \\
\text { ge at first birth } \\
\text { e }(<45,45-49 \text {, } \\
\text { atory batch. }\end{array}$ \\
\hline
\end{tabular}

Among the three mammographic density parameters we analysed, we observed the strongest associations between sex hormone levels and SHBG on the absolute area of non-dense mammographic tissue. Non-dense tissue on the mammogram consists of adipose tissue and is highly correlated with BMI (Haars et al, 2005; Boyd et al, 2006). In postmenopausal women, oestrogen production mostly arises through aromatase activity converting androgens in adipose tissue after cessation of ovarian function (Folkerd et al, 2006). Women with high BMI have therefore higher aromatase levels and lower levels of SHBG and as a consequence higher total and free oestradiol levels than women with lower BMI. They also have, for unclear reasons, increased testosterone and androstenedione levels (Folkerd et al, 2006; Key et al, 2011). For percentage density, we observed significant inverse associations with sex hormone levels but not significant associations after adjustment for BMI. The influence of BMI on relative density is thought to be entirely due to an effect of non-dense tissue (Haars et al, 2005) and it is conventional to adjust percentage density for BMI (and age) because a particular level of percentage density in a woman with low BMI does not represent the same amount of dense tissue as in a woman with high BMI, owing to high BMI being associated with more non-dense area and larger total breast size. The use of an absolute rather than relative measure of dense area can reduce or eliminate confounding by BMI (Assi et al, 2012). In our study, absolute dense area was less strongly negatively associated with oestradiol and similarly associated with testosterone levels as percentage dense area, suggesting an influence of sex hormone levels on dense area. Additional adjustment for BMI to explore residual confounding showed weaker nonsignificant associations, but it is questionable whether inclusion of BMI represents overadjustment because BMI and sex hormone levels are on the same pathway. Previous studies of the association between sex hormone levels and density have shown inconsistent results, with some reporting an inverse (Boyd et al, 2002b; Aiello et al, 2005), positive (Greendale et al, 2005; Bremnes et al, 2007; Johansson et al, 2008) or no association (Tamimi et al, 2005; Warren et al, 2006; Verheus et al, 2007; McCormack et al, 2009; Sprague et al, 2011) with circulating sex hormone levels after adjusting for adiposity.

The positive association of SHBG levels with percentage and absolute dense area in our study, which remained after adjusting for BMI, is supported by some (Boyd et al, 2002b; Greendale et al, 2005; Tamimi et al, 2005; Warren et al, 2006; Bremnes et al, 2007; Johansson et al, 2008; Sprague et al, 2011; Woolcott et al, 2013), but not all (Aiello et al, 2005; Verheus et al, 2007; McCormack et al, 2009) past studies. Our findings suggest that SHBG independently affects density because the association remained significant after adjustment for oestradiol or testosterone. Other hormones could potentially also affect density, such as progesterone (Sprague et al, 2011; Lee et al, 2012), because associations with density have been stronger for combined HT than solely for oestrogen HT (Martin et al, 2009), or prolactin, which has been 
Table 5. Odds ratios for incident breast cancer in relation to tertiles of plasma sex hormone and SHBG level and percentage mammographic density, Breakthrough Generations Study, United Kingdom

Percentage mammographic density (\%), tertiles ${ }^{a}$

\begin{tabular}{|c|c|c|c|c|c|c|}
\hline \multirow{2}{*}{$\begin{array}{l}\text { Sex hormone or SHBG level } \\
\text { (tertiles) }\end{array}$} & \multicolumn{2}{|c|}{$1 \mathrm{st}$} & \multicolumn{2}{|c|}{ 2nd } & \multicolumn{2}{|c|}{ 3rd } \\
\hline & Cases/controls & $\mathrm{OR}^{\mathrm{b}}(95 \% \mathrm{Cl})$ & Cases/controls & $\mathrm{OR}^{\mathrm{b}}(95 \% \mathrm{Cl})$ & Cases/controls & $\mathrm{OR}^{\mathrm{b}}(95 \% \mathrm{Cl})$ \\
\hline \multicolumn{7}{|l|}{ Oestradiol $^{c}$} \\
\hline $\begin{array}{l}1 \text { st } \\
\text { 2nd } \\
3 \text { rd }\end{array}$ & $\begin{array}{l}11 / 31 \\
17 / 38 \\
28 / 41\end{array}$ & $\begin{array}{c}1.00 \\
1.53(0.54-4.37) \\
2.88(1.04-8.02)\end{array}$ & $\begin{array}{l}25 / 34 \\
28 / 33 \\
35 / 44\end{array}$ & $\begin{array}{l}2.60(0.96-7.05) \\
4.18(1.55-11.3) \\
3.68(1.39-9.76)\end{array}$ & $\begin{array}{l}38 / 45 \\
33 / 37 \\
47 / 27\end{array}$ & $\begin{array}{c}2.97(1.16-7.60) \\
2.58(0.98-6.80) \\
7.81(2.89-21.1) \\
P \text { interaction }{ }^{d}=0.276\end{array}$ \\
\hline
\end{tabular}

\begin{tabular}{|c|c|c|c|c|c|c|}
\hline \multicolumn{7}{|c|}{ Free oestradiol $^{\mathrm{C}}$} \\
\hline $\begin{array}{l}\text { 1st } \\
\text { 2nd } \\
3 \text { rd }\end{array}$ & $\begin{array}{l}12 / 34 \\
15 / 38 \\
29 / 38\end{array}$ & $\begin{array}{c}1.00 \\
1.21(0.43-3.42) \\
3.17(1.17-8.63)\end{array}$ & $\begin{array}{l}25 / 30 \\
32 / 37 \\
31 / 44\end{array}$ & $\begin{array}{l}3.15(1.18-8.36) \\
4.02(1.57-10.3) \\
2.88(1.11-7.74)\end{array}$ & $\begin{array}{l}44 / 46 \\
28 / 34 \\
46 / 29\end{array}$ & $\begin{array}{c}3.34(1.37-8.15) \\
2.53(0.97-6.57) \\
6.23(2.40-16.2) \\
P \text { interaction }{ }^{d}=0.116\end{array}$ \\
\hline \multicolumn{7}{|c|}{ Testosterone $e^{c}$} \\
\hline $\begin{array}{l}\text { 1st } \\
\text { 2nd } \\
\text { 3rd }\end{array}$ & $\begin{array}{l}10 / 36 \\
23 / 35 \\
23 / 40\end{array}$ & $\begin{array}{c}1.00 \\
2.18(0.80-5.95) \\
2.18(0.79-5.99)\end{array}$ & $\begin{array}{l}31 / 35 \\
26 / 44 \\
31 / 32\end{array}$ & $\begin{array}{l}3.91(1.46-10.5) \\
2.61(0.95-7.11) \\
4.23(1.59-11.3)\end{array}$ & $\begin{array}{l}33 / 39 \\
40 / 33 \\
45 / 39\end{array}$ & $\begin{array}{c}2.96(1.10-7.95) \\
4.60(1.75-12.1) \\
4.57(1.75-11.9) \\
P \text { interaction }^{\mathrm{d}}=0.434\end{array}$ \\
\hline
\end{tabular}

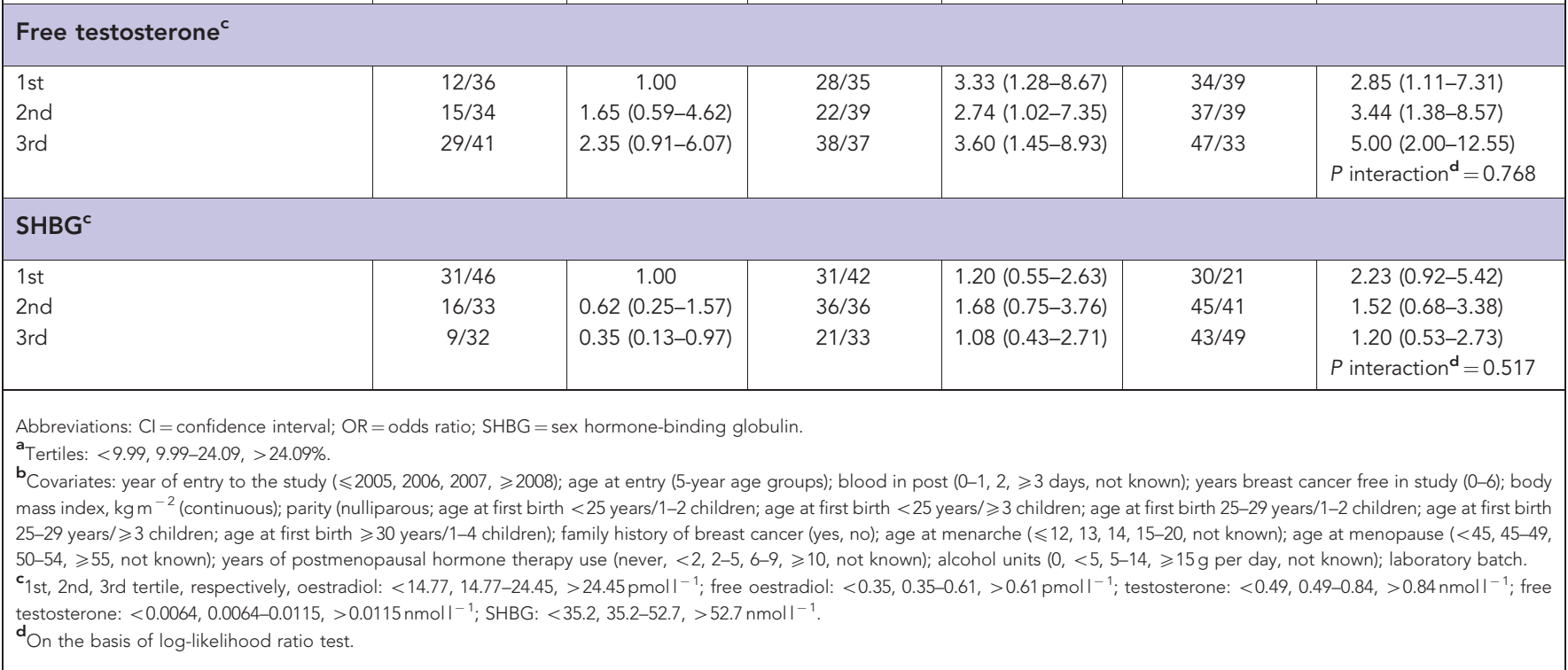

positively associated with density in some, but not all, studies (Boyd et al, 2002b; Tamimi et al, 2005; Bremnes et al, 2007; Greendale et al, 2007). Recent reports also suggest that the extent and pathway of oestrogen metabolism is associated with density (Fuhrman et al, 2012).

The mechanisms through which sex hormones, BMI and density contribute to breast cancer risk are complex and incompletely understood. It is thought that oestrogens promote breast cancer progression by increasing proliferation of breast epithelial tissue, but it has also been suggested that oestrogens and their hydroxylated metabolites may act as carcinogens (Folkerd et al, 2006). The association of BMI with breast cancer risk is probably due to increased sex hormone levels rather than an effect of BMI per se (Key et al, 2003). Mammographic density has been proposed to represent the cumulative exposure of tissue to hormones and growth factors that stimulate cell division and it has been hypothesised that such exposures at young ages, during the greatest susceptibility of the breast according to the Pike Model (Pike et al, 1983), is related to tissue composition (Boyd et al, 2010). The well-established associations of density with parity, combined HT use and tamoxifen (Martin et al, 2009; Boyd et al, 2011) provide evidence for both endogenous and exogenous sex hormone levels as important determinants of density. The extent of dense tissue might also simply raise cancer risk because such tissue has more epithelial cells and thus a higher risk of transformation, and because there is more communication of epithelial cells with connective tissue, which produces hormones and growth factors (Polyak and Kalluri, 2010). An independent protective role of non-dense tissue on breast carcinogenesis has recently been reported (Pettersson et al, 2011), despite adipose tissue being an important source of oestrogens.

The independence in effects of postmenopausal sex hormone levels and density on breast cancer risk in our study suggests that 


\begin{tabular}{|c|c|c|c|}
\hline & \multicolumn{3}{|c|}{ Percentage mammographic density (\%), tertiles ${ }^{a}$} \\
\hline & $1 \mathrm{st}$ & 2nd & $3 r d$ \\
\hline \multicolumn{4}{|c|}{ Cumulative risk of breast cancer between ages } \\
\hline \multicolumn{4}{|c|}{ Oestradiol, tertiles ${ }^{b}$} \\
\hline \multicolumn{4}{|c|}{ Age: $50-69$ years } \\
\hline $\begin{array}{l}\text { 1st } \\
\text { 2nd } \\
3 r d\end{array}$ & $\begin{array}{l}1.7(0.61-4.9) \\
2.7(0.95-7.4) \\
4.9(1.8-13.2)\end{array}$ & $\begin{array}{l}4.5(1.7-11.7) \\
7.1(2.7-17.9) \\
6.3(2.4-15.7)\end{array}$ & $\begin{array}{r}5.1(2.0-12.4) \\
4.4(1.7-11.3) \\
12.8(4.9-30.7)\end{array}$ \\
\hline \multicolumn{4}{|c|}{ Age: $20-79$ years } \\
\hline $\begin{array}{l}1 \mathrm{st} \\
2 \mathrm{nd} \\
3 \mathrm{rd}\end{array}$ & $\begin{array}{l}4.3(2.7-8.6) \\
5.6(3.2-11.9) \\
8.8(4.4-19.9)\end{array}$ & $\begin{array}{r}8.1(4.2-17.8) \\
11.7(5.6-25.9) \\
10.6(5.2-23.2)\end{array}$ & $\begin{array}{r}9.0(4.7-18.9) \\
8.0(4.2-17.2) \\
19.4(8.8-42.0)\end{array}$ \\
\hline $\begin{array}{l}\mathbf{a}_{\text {Tert }} \\
\mathbf{b}_{\text {Tert }}\end{array}$ & $\begin{array}{l}\text { ographic density: }<9 \text {. } \\
\text { tiol: }<14.77,14.77-24\end{array}$ & $\begin{array}{l}4.09,>24.09 \% \\
45 \mathrm{pmoll}^{-1}\end{array}$ & \\
\hline
\end{tabular}

current sex hormone levels are a poor proxy for cumulative hormonal exposures, or that other forms of oestrogens not measured in this study have a role or that there are other important pathways involved. Positive associations of density with IGF I and IGFBP3 levels have been reported in some studies, although these associations appear to be confined to premenopausal women (dos Santos Silva et al, 2006; Bremnes et al, 2007; Becker and Kaaks, 2009; McCormack et al, 2009; Rice et al, 2012). The heritability of density is estimated as $63 \%$ from twin studies (Boyd et al, 2002a) and breast cancer susceptibility variants in genes LSP1, RAD51L1 (Vachon et al, 2012) and ZNF365 (Lindstrom et al, 2011), and at 12q24 (Stevens et al, 2012) have also been associated with density; therefore, density and breast cancer might have a shared genetic basis.

Our results are supported by the only previous report of combined effects of density and sex hormones on breast cancer risk, a case-control analysis including 253 cases from the Nurses' Health Study, which reported that women in the top tertile of percentage density and oestradiol or testosterone were at four- and six-fold risk of breast cancer, respectively, compared with those in the lowest tertiles for both (Tamimi et al, 2007). Associations of breast cancer risk with sex hormone levels, irrespective of density, were of similar magnitude in our study to that by Tamimi et al (2007), but associations of risk with density, irrespective of sex hormone levels, were weaker, despite a very similar distribution of percentage density among controls. However, when we categorised density using cut-points frequently used by others rather than quartiles of our data, our results were comparable to those of a pooled analyses of three Canadian studies (Boyd et al, 2011).

We could not retrieve prediagnostic mammograms for all cases and controls, and women with retrieved mammograms were older and therefore more often postmenopausal than those for whom we were unsuccessful, likely to be a reflection of older women having longer asymptomatic screening histories and therefore a higher probability that a set of mammograms can be retrieved from a screening centre. For cases this age difference was more pronounced than for controls because younger cases had a shorter or no asymptomatic screening history owing to screen-detected breast cancers. There was, however, no appreciable difference in mean age at entry or menopausal status between cases and controls with retrieved mammograms. A smaller proportion of cases than controls were eligible for hormone analyses owing to cases being more likely to be on HT at blood draw, which resulted in a lower prevalence of past HT use among included cases compared with controls.

Limitations of our study are that sex hormone assessments were based on a single plasma sample and density was evaluated at a single time point and that the sex hormone and mammographic density measures were collected at a median of 1.2 (controls) or 1.5 (cases) years apart, which is likely to have weakened associations. For sex hormone levels the observed OR of association is likely to be an underestimate of the true association because a single measurement is an imperfect estimate of the true pattern over several years that presumably matters, owing to within-person variation and assay variation. Zhang et al (2013) recently assessed the reliability of a single measurement of plasma oestradiol and testosterone by measuring these hormones in samples taking from postmenopausal women 10 years apart and observed an intraclass correlation coefficient of 0.69 for total oestradiol and 0.71 for total testosterone. They concluded that single plasma measurements of oestradiol and testosterone were predictive of breast cancer for up to 16-20 years. Mammographic density measurements have interand intrareader variability (Boyd et al, 2011), although readings with Cumulus have been shown to be highly reliable (McCormack et al, 2007). Associations of postmenopausal breast cancer risk with mammographic density have been reported to persist for up to 10 years after the mammogram (Yaghjyan et al, 2013).

Our study had very limited precision to estimate combined effects in subgroups of women. It is possible that ORs for combined effects are higher in women who have never used HT, as suggested by the previous study by Tamimi et al (2007) and by stronger associations with endogenous oestradiol in such women in a large pooled analysis (Key et al, 2002). Furthermore, ORs are likely to be higher for ER-positive breast cancer than for breast cancer overall, because it has been suggested that sex hormone associations are limited to ER-positive cancer (Tamimi et al, 2007; Zhang et al, 2013), but receptor status is not currently available for enough subjects in our data set to confirm or refute this. Pooling of data sets will be needed to investigate combined effects by hormone receptor status of the breast cancer, former HT use or other factors such as BMI and family history of breast cancer.

Mammographic density information is not yet routinely collected at screening in the United Kingdom and has not yet been included in published risk prediction models or been incorporated into breast cancer screening strategies. The use of Cumulus or similar programmes is labour intensive and requires thorough operator training, making it unsuitable for high volume processing. The introduction of digital mammography into the National Breast Cancer Screening Programme and recently developed high-throughput methods to assess mammographic density could help facilitate collection of such information on a large scale (Li et al, 2012; Skippage et al, 2013). Our study suggests that information on density and sex hormone levels combined might have additional predictive power, but a standardised assay for oestradiol would need to be developed for postmenopausal women which is suitable for incorporation into clinical practice (Dowsett and Folkerd, 2005; Lee et al, 2006). This could help tailor screening frequencies as well as screening modalities, and could aid clinical decision-making with regard to prophylactic measures.

We conclude that prior circulating oestradiol and testosterone levels as well as mammographic density appear to be independent risk factors for postmenopausal breast cancer, and that women with high levels of both sex hormones and density have levels of cumulative breast cancer risk that might require increased screening frequencies and chemoprophylaxis. 


\section{ACKNOWLEDGEMENTS}

We thank Jean Hoare, Nicola Quispe and Zoe Gallant for help with retrieving mammograms, mammogram digitisation and density readings. We also thank Dr Anoma Gunasekara from Sunnybrook Health Sciences Centre, Toronto, and Dr Valerie McCormack from the International Agency for Research on Cancer, Lyon, for valuable advice regarding the use of Cumulus and Dr Necdet Gunsoy for advice regarding cumulative risk calculations. We express our thanks to the regional breast cancer screening centres in the United Kingdom for loaning mammograms. The Breakthrough Generations Study thank Breakthrough Breast Cancer, the Institute of Cancer Research and the Da Costa Foundation for support and funding of the Breakthrough Generations Study, and the study participants, study staff, and the doctors, nurses and other health-care staff and data providers who have contributed to the Study. We acknowledge NHS funding to the NIHR Biomedical Research Centre for Cancer.

\section{CONFLICT OF INTEREST}

The authors declare no conflict of interest.

\section{DISCLAIMER}

The sponsors of the study had no role in study design, data collection, data analysis, data interpretation or writing of the report. The authors had full access to the data in the study and had the full responsibility for the decision to submit the manuscript for publication.

\section{AUTHOR CONTRIBUTIONS}

MD and AJS designed and obtained funding for the study, MD and EJF designed and supervised the laboratory assays and MR carried out the laboratory work. SA contributed to data collection and mammographic density readings. AA, AJS, MEJ and MJS set up and collected data in the Breakthrough Generations Study and AJS and MEJ contributed to data collection for the substudy. MJS oversaw data collection, conducted the analyses and drafted the manuscript. All authors contributed to data interpretation and writing of the manuscript.

\section{REFERENCES}

Aiello EJ, Tworoger SS, Yasui Y, Stanczyk FZ, Potter J, Ulrich CM, Irwin M, McTiernan A (2005) Associations among circulating sex hormones, insulinlike growth factor, lipids, and mammographic density in postmenopausal women. Cancer Epidemiol Biomarkers Prev 14: 1411-1417.

Assi V, Warwick J, Cuzick J, Duffy SW (2012) Clinical and epidemiological issues in mammographic density. Nat Rev Clin Oncol 9: 33-40.

Becker S, Kaaks R (2009) Exogenous and endogenous hormones, mammographic density and breast cancer risk: can mammographic density be considered an intermediate marker of risk? Recent Results Cancer Res 181: 135-157.

Boyd NF, Dite GS, Stone J, Gunasekara A, English DR, McCredie MR, Giles GG, Tritchler D, Chiarelli A, Yaffe MJ, Hopper JL (2002a) Heritability of mammographic density, a risk factor for breast cancer. N Engl J Med 347: 886-894.

Boyd NF, Martin LJ, Bronskill M, Yaffe MJ, Duric N, Minkin S (2010) Breast tissue composition and susceptibility to breast cancer. J Natl Cancer Inst 102: $1224-1237$.
Boyd NF, Martin LJ, Sun L, Guo H, Chiarelli A, Hislop G, Yaffe M, Minkin S (2006) Body size, mammographic density, and breast cancer risk. Cancer Epidemiol Biomarkers Prev 15: 2086-2092.

Boyd NF, Martin LJ, Yaffe MJ, Minkin S (2011) Mammographic density and breast cancer risk: current understanding and future prospects. Breast Cancer Res 13: 223.

Boyd NF, Stone J, Martin LJ, Jong R, Fishell E, Yaffe M, Hammond G, Minkin S (2002b) The association of breast mitogens with mammographic densities. Br J Cancer 87: 876-882.

Bremnes Y, Ursin G, Bjurstam N, Rinaldi S, Kaaks R, Gram IT (2007) Endogenous sex hormones, prolactin and mammographic density in postmenopausal Norwegian women. Int J Cancer 121: 2506-2511.

Byng JW, Boyd NF, Fishell E, Jong RA, Yaffe MJ (1994) The quantitative analysis of mammographic densities. Phys Med Biol 39: 1629-1638.

dos Santos Silva I, Johnson N, De Stavola B, Torres-Mejía G, Fletcher O, Allen DS, Allen NE, Key TJ, Fentiman IS, Holly JMP, Peto J (2006) The insulin-like growth factor system and mammographic features in premenopausal and postmenopausal women. Cancer Epidemiol Biomarkers Prev 15: 449-455.

Dowsett M, Folkerd E (2005) Deficits in plasma oestradiol measurement in studies and management of breast cancer. Breast Cancer Res 7: 1-4.

Folkerd EJ, Martin LA, Kendall A, Dowsett M (2006) The relationship between factors affecting endogenous oestradiol levels in postmenopausal women and breast cancer. J Steroid Biochem Mol Biol 102: 250-255.

Fuhrman BJ, Brinton LA, Pfeiffer RM, Xu X, Veenstra TD, Teter BE, Byrne C, Dallal CM, Barba M, Muti PC, Gierach GL (2012) Estrogen metabolism and mammographic density in postmenopausal women: a cross-sectional study. Cancer Epidemiol Biomarkers Prev 21: 1582-1591.

Gail MH, Brinton LA, Byar DP, Corle DK, Green SB, Schairer C, Mulvihill JJ (1989) Projecting individualized probabilities of developing breast cancer for white females who are being examined annually. J Natl Cancer Inst 81: 1879-1886.

Greendale GA, Huang MH, Ursin G, Ingles S, Stanczyk F, Crandall C, Laughlin GA, Barrett-Connor E, Karlamangla A (2007) Serum prolactin levels are positively associated with mammographic density in postmenopausal women. Breast Cancer Res Treat 105: 337-346.

Greendale GA, Palla SL, Ursin G, Laughlin GA, Crandall C, Pike MC, Reboussin BA (2005) The association of endogenous sex steroids and sex steroid binding proteins with mammographic density: results from the Postmenopausal Estrogen/Progestin Interventions Mammographic Density Study. Am J Epidemiol 162: 826-834.

Haars G, van Noord PA, van Gils CH, Grobbee DE, Peeters PH (2005) Measurements of breast density: no ratio for a ratio. Cancer Epidemiol Biomarkers Prev 14: 2634-2640.

Johansson H, Gandini S, Bonanni B, Mariette F, Guerrieri-Gonzaga A, Serrano D, Cassano E, Ramazzotto F, Baglietto L, Sandri MT, Decensi A (2008) Relationships between circulating hormone levels, mammographic percent density and breast cancer risk factors in postmenopausal women. Breast Cancer Res Treat 108: 57-67.

Jones ME, Folkerd EJ, Doody DA, Iqbal J, Dowsett M, Ashworth A, Swerdlow AJ (2007) Effect of delays in processing blood samples on measured endogenous plasma sex hormone levels in women. Cancer Epidemiol Biomarkers Prev 16: 1136-1139.

Key T, Appleby P, Barnes I, Reeves G (2002) Endogenous sex hormones and breast cancer in postmenopausal women: reanalysis of nine prospective studies. J Natl Cancer Inst 94: 606-616.

Key TJ, Appleby PN, Reeves GK, Roddam A, Dorgan JF, Longcope C, Stanczyk FZ, Stephenson Jr HE, Falk RT, Miller R, Schatzkin A, Allen DS, Fentiman IS, Key TJ, Wang DY, Dowsett M, Thomas HV, Hankinson SE, Toniolo P, Akhmedkhanov A, Koenig K, Shore RE, Zeleniuch-Jacquotte A, Berrino F, Muti P, Micheli A, Krogh V, Sieri S, Pala V, Venturelli E, Secreto G, Barrett-Connor E, Laughlin GA, Kabuto M, Akiba S, Stevens RG, Neriishi K, Land CE, Cauley JA, Kuller LH, Cummings SR, Helzlsouer KJ, Alberg AJ, Bush TL, Comstock GW, Gordon GB, Miller SR, Longcope C (2003) Body mass index, serum sex hormones, and breast cancer risk in postmenopausal women. J Natl Cancer Inst 95: 1218-1226.

Key TJ, Appleby PN, Reeves GK, Roddam AW, Helzlsouer KJ, Alberg AJ, Rollison DE, Dorgan JF, Brinton LA, Overvad K, Kaaks R, Trichopoulou A, Clavel-Chapelon F, Panico S, Duell EJ, Peeters PH, Rinaldi S, Fentiman IS, Dowsett M, Manjer J, Lenner P, Hallmans G, Baglietto L, English DR, Giles GG, Hopper JL, Severi G, Morris HA, Hankinson SE, Tworoger SS, Koenig K, Zeleniuch-Jacquotte A, Arslan AA, Toniolo P, Shore RE, Krogh V, Micheli A, Berrino F, Barrett-Connor E, Laughlin GA, Kabuto M, Akiba S, 
Stevens RG, Neriishi K, Land CE, Cauley JA, Lui LY, Cummings SR, Gunter MJ, Rohan TE, Strickler HD (2011) Circulating sex hormones and breast cancer risk factors in postmenopausal women: reanalysis of 13 studies. Br J Cancer 105: 709-722.

Lee E, Ingles SA, Van Den BD, Wang W, Lavallee C, Huang MH, Crandall CJ, Stanczyk FZ, Greendale GA, Ursin G (2012) Progestogen levels, progesterone receptor gene polymorphisms, and mammographic density changes: results from the Postmenopausal Estrogen/Progestin Interventions Mammographic Density Study. Menopause 19: 302-310.

Lee JS, Ettinger B, Stanczyk FZ, Vittinghoff E, Hanes V, Cauley JA, Chandler W, Settlage J, Beattie MS, Folkerd E, Dowsett M, Grady D, Cummings SR (2006) Comparison of methods to measure low serum estradiol levels in postmenopausal women. J Clin Endocrinol Metab 91: 3791-3797.

Li J, Humphreys K, Eriksson L, Edgren G, Czene K, Hall P (2013) Mammographic density reduction is a prognostic marker of response to adjuvant tamoxifen therapy in postmenopausal patients with breast cancer. J Clin Oncol 31: 2249-2256.

Li J, Szekely L, Eriksson L, Heddson B, Sundbom A, Czene K, Hall P, Humphreys K (2012) High-throughput mammographic-density measurement: a tool for risk prediction of breast cancer. Breast Cancer Res 14: R114.

Lindstrom S, Vachon CM, Li J, Varghese J, Thompson D, Warren R, Brown J, Leyland J, Audley T, Wareham NJ, Loos RJ, Paterson AD, Rommens J, Waggott D, Martin LJ, Scott CG, Pankratz VS, Hankinson SE, Hazra A, Hunter DJ, Hopper JL, Southey MC, Chanock SJ, Silva IS, Liu J, Eriksson L, Couch FJ, Stone J, Apicella C, Czene K, Kraft P, Hall P, Easton DF, Boyd NF, Tamimi RM (2011) Common variants in ZNF365 are associated with both mammographic density and breast cancer risk. Nat Genet 43: 185-187.

Martin LJ, Minkin S, Boyd NF (2009) Hormone therapy, mammographic density, and breast cancer risk. Maturitas 64: 20-26.

McCormack VA, Highnam R, Perry N, dos Santos Silva I (2007) Comparison of a new and existing method of mammographic density measurement: intramethod reliability and associations with known risk factors. Cancer Epidemiol Biomarkers Prev 16: 1148-1154.

McCormack V, Dowsett M, Folkerd E, Johnson N, Palles C, Coupland B, Holly J, Vinnicombe S, Perry N, dos Santos Silva I (2009) Sex steroids, growth factors and mammographic density: a cross-sectional study of UK postmenopausal Caucasian and Afro-Caribbean women. Breast Cancer Res 11: R38.

National Institute for Health and Care Excellence (2013) Familial Breast Cancer: Classification and care of people at risk of familial breast cancer and management of breast cancer and related risks in people with a family history of breast cancer. NICE Clinical Guideline. Vol 164. NICE, Manchester, UK.

Parkin DM (2009) Is the recent fall in incidence of post-menopausal breast cancer in UK related to changes in use of hormone replacement therapy? Eur J Cancer 45: 1649-1653.

Pettersson A, Hankinson SE, Willett WC, Lagiou P, Trichopoulos D, Tamimi RM (2011) Nondense mammographic area and risk of breast cancer. Breast Cancer Res 13: R100.

Pike MC, Krailo MD, Henderson BE, Casagrande JT, Hoel DG (1983) 'Hormonal' risk factors, 'breast tissue age' and the age-incidence of breast cancer. Nature 303: 767-770.

Polyak K, Kalluri R (2010) The role of the microenvironment in mammary gland development and cancer. Cold Spring Harb Perspect Biol 2: a003244.

Reeves GK, Beral V, Green J, Gathani T, Bull D (2006) Hormonal therapy for menopause and breast-cancer risk by histological type: a cohort study and meta-analysis. Lancet Oncol 7: 910-918.

Rice MS, Tworoger SS, Rosner BA, Pollak MN, Hankinson SE, Tamimi RM (2012) Insulin-like growth factor-1, insulin-like growth factor-binding protein-3, growth hormone, and mammographic density in the Nurses' Health Studies. Breast Cancer Res Treat 136: 805-812.

Rinaldi S, Geay A, Dechaud H, Biessy C, Zeleniuch-Jacquotte A, Akhmedkhanov A, Shore RE, Riboli E, Toniolo P, Kaaks R (2002) Validity of free testosterone and free estradiol determinations in serum samples from postmenopausal women by theoretical calculations. Cancer Epidemiol Biomarkers Prev 11: 1065-1071.

Rothman KJ (1986) Modern Epidemiology. Brown and Company: Boston, MA, USA.

Skippage P, Wilkinson L, Allen S, Roche N, Dowsett M, A'hern R (2013) Correlation of age and HRT use with breast density as assessed by Quantra. Breast J 19: 79-86.
Sprague BL, Trentham-Dietz A, Gangnon RE, Buist DS, Burnside ES, Bowles EJ, Stanczyk FZ, Sisney GS (2011) Circulating sex hormones and mammographic breast density among postmenopausal women. Horm Cancer 2: 62-72.

Stevens KN, Lindstrom S, Scott CG, Thompson D, Sellers TA, Wang X, Wang A, Atkinson E, Rider DN, Eckel-Passow JE, Varghese JS, Audley T, Brown J, Leyland J, Luben RN, Warren RM, Loos RJ, Wareham NJ, Li J, Hall P, Liu J, Eriksson L, Czene K, Olson JE, Pankratz VS, Fredericksen Z, Diasio RB, Lee AM, Heit JA, DeAndrade M, Goode EL, Vierkant RA, Cunningham JM, Armasu SM, Weinshilboum R, Fridley BL, Batzler A, Ingle JN, Boyd NF, Paterson AD, Rommens J, Martin LJ, Hopper JL, Southey MC, Stone J, Apicella C, Kraft P, Hankinson SE, Hazra A, Hunter DJ, Easton DF, Couch FJ, Tamimi RM, Vachon CM (2012) Identification of a novel percent mammographic density locus at 12q24. Hum Mol Genet 21: 3299-3305.

Swerdlow AJ, Jones ME, Schoemaker MJ, Hemming J, Thomas D, Williamson J, Ashworth A (2011) The Breakthrough Generations Study: design of a long-term UK cohort study to investigate breast cancer aetiology. Br J Cancer 105: 911-917.

Tamimi RM, Byrne C, Colditz GA, Hankinson SE (2007) Endogenous hormone levels, mammographic density, and subsequent risk of breast cancer in postmenopausal women. J Natl Cancer Inst 99: 1178-1187.

Tamimi RM, Hankinson SE, Colditz GA, Byrne C (2005) Endogenous sex hormone levels and mammographic density among postmenopausal women. Cancer Epidemiol Biomarkers Prev 14: 2641-2647.

Vachon CM, Scott CG, Fasching PA, Hall P, Tamimi RM, Li J, Stone J, Apicella C, Odefrey F, Gierach GL, Jud SM, Heusinger K, Beckmann MW, Pollan M, Fernandez-Navarro P, Gonzalez-Neira A, Benitez J, van Gils CH, Lokate M, Onland-Moret NC, Peeters PH, Brown J, Leyland J, Varghese JS, Easton DF, Thompson DJ, Luben RN, Warren RM, Wareham NJ, Loos RJ, Khaw KT, Ursin G, Lee E, Gayther SA, Ramus SJ, Eeles RA, Leach MO, Kwan-Lim G, Couch FJ, Giles GG, Baglietto L, Krishnan K, Southey MC, Le Marchand L, Kolonel LN, Woolcott C, Maskarinec G, Haiman CA, Walker K, Johnson N, McCormack VA, Biong M, Alnaes GI, Gram IT, Kristensen VN, Borresen-Dale AL, Lindstrom S, Hankinson SE, Hunter DJ, Andrulis IL, Knight JA, Boyd NF, Figuero JD, Lissowska J, Wesolowska E, Peplonska B, Bukowska A, Reszka E, Liu J, Eriksson L, Czene K, Audley T, Wu AH, Pankratz VS, Hopper JL, dos-Santos-Silva I (2012) Common breast cancer susceptibility variants in LSP1 and RAD51L1 are associated with mammographic density measures that predict breast cancer risk. Cancer Epidemiol Biomarkers Prev 21: 1156-1166.

VanderWeele TJ, Knol MJ (2013) A tutorial on interaction. Epidemiol Methods (in press).

Verheus M, Peeters PH, van Noord PA, van der Schouw YT, Grobbee DE, van Gils CH (2007) No relationship between circulating levels of sex steroids and mammographic breast density: the Prospect-EPIC cohort. Breast Cancer Res 9: R53.

Warren R, Skinner J, Sala E, Denton E, Dowsett M, Folkerd E, Healey CS, Dunning A, Doody D, Ponder B, Luben RN, Day NE, Easton D (2006) Associations among mammographic density, circulating sex hormones, and polymorphisms in sex hormone metabolism genes in postmenopausal women. Cancer Epidemiol Biomarkers Prev 15: 1502-1508.

Woolcott CG, Courneya KS, Boyd NF, Yaffe MJ, McTiernan A, Brant R, Jones CA, Stanczyk FZ, Terry T, Cook LS, Wang Q, Friedenreich CM (2013) Association between sex hormones, glucose homeostasis, adipokines, and inflammatory markers and mammographic density among postmenopausal women. Breast Cancer Res Treat 139: 255-265.

Yaghjyan L, Colditz GA, Rosner B, Tamimi RM (2013) Mammographic breast density and subsequent risk of breast cancer in postmenopausal women according to the time since the mammogram. Cancer Epidemiol Biomarkers Prev 22: 1110-1117.

Zhang X, Tworoger SS, Eliassen AH, Hankinson SE (2013) Postmenopausal plasma sex hormone levels and breast cancer risk over 20 years of follow-up. Breast Cancer Res Treat 137: 883-892.

This work is published under the standard license to publish agreement. After 12 months the work will become freely available and the license terms will switch to a Creative Commons AttributionNonCommercial-Share Alike 3.0 Unported License. 